\title{
Prevalence of Antenatal Care Practice among Marginalized Community of Nepal
}

\author{
Raj Kumar Sangroula ${ }^{1}$, Subash Khatiwada ${ }^{1}$, Maginsh Dahal ${ }^{2 *}, K^{*}$ shalata Baral ${ }^{3}$, Bhuwan Thakurathi ${ }^{4}$ \\ Ramesh Barakoti ${ }^{5}$, Menuka Sangroula ${ }^{6}$, Sudip Khanal ${ }^{3}$, Raj Kumar Subedi ${ }^{7}$
}

\author{
Author Info: \\ ${ }^{1}$ Department of Public Health, \\ Little Buddha College of Health \\ Sciences, Kathmandu, Nepal \\ ${ }^{2}$ School of Public Health, Nanjing \\ Medical University, Nanjing, \\ China \\ ${ }^{3}$ Department of Public Health, \\ Nobel College, Pokhara \\ University, Sinamangal \\ Kathmandu, Nepal \\ ${ }^{4}$ Khaptad Medical Studies and \\ Health Sciences, Dhangadhi, \\ Kailali, Nepal \\ ${ }^{5}$ Health Office, Sankhuwasava, \\ Province 1, Government of Nepal \\ ${ }^{6}$ Department of Medicine, \\ Manmohan Memorial Hospital, \\ Kathmandu, Nepal \\ ${ }^{7}$ Department of Research, \\ Bhaskar-Tejshree Memorial \\ Foundation, Kathmandu, Nepal \\ Corresponding Author: \\ MaginshDahal \\ PhD Scholar \\ School of Public Health, Nanjing \\ Medical University, Nanjing, \\ China \\ Email:- maginsh@gmail.com
}

\begin{abstract}
Background: The government of Nepal aims to improve the health of mothers and newborns by providing quality safe motherhood services. Increasing access and utilization of antenatal care (ANC) services are the first steps towards improving maternal and neonatal health outcomes, particularly those of the marginalized communities.

Objective: The aim of this study is to assess the prevalence and factors associated with the antenatal care visits among the marginalized community of Nepal.

Methods: A mixed-method study was conducted among 202 reproductive aged females of marginalized community in Nepal having childbirth during the last 2 years. Pre-tested semi-structured questionnaires and key informant interview guidelines were used for the collection of data. Bivariate and multiple regression analysis were carried out to find out the factors associated with the antenatal care visits. For qualitative data, thematic analysis was done.

Results: More than half (56.9\%) of the participants had completed four or more antenatal care visits. Mothers with primary level of education were 2.7 times more likely to complete four or more ANC visits (AOR: 2.7, Cl: 1.09-7.07). Age at marriage (AOR: 2.3, Cl: 1.08-5.22), women who took decisions alone for their health (AOR: 2.9, Cl: 1.22-6.96), exposure to FCHV (AOR:2.5, Cl: 1.1-5.9), knowledge about safe delivery incentive program (AOR: 3.6, $\mathrm{Cl}$ : 1.46-9.0) and perception of "good quality" ANC service(AOR:7.5, Cl: 3.3-17.1)were significantly associated with the number of ANC visits.

Conclusion: The overall utilization of antenatal health services was low. So, there is a need of different community based maternal health programs especially targeting the marginalized females.
\end{abstract}

Keywords: Antenatal Care, Female community health volunteers, Marginalized communities, ANC, FCHV

\section{QR Code}

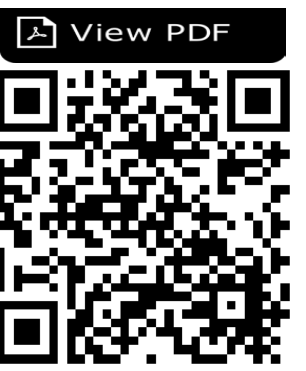

Scan Me for Full Text

\section{Article Info}

Received: 28 August 2020; Accepted: 29 December 2020; Published Online: 30 December 2020

\section{How to cite this article in Vancouver Style?}

Sangroula RK, Khatiwada S, Dahal M, Baral K, Thakurathi B, Barakoti R, Sangroula M, Khanal S, Subedi RK, Subedi RK. Prevalence of Antenatal Care Practice among Marginalized Community of Nepal. Europasian J Med Sci.2020;2(2):84-91. https://doi.org/10.46405/ejms.v2i2.197

\section{Disclaimer:}

Conflict of Interest: None Declared;

\section{Source of Support: Nil}

Copyright: $\odot 2020$ by author(s). This is an open access article distributed under the terms of the Creative Commons Attribution International License 4.0@ @- (1) which permits unrestricted use, distribution, and reproduction in any medium, provided the original work is properly cited.

\section{Publisher's Note:}

The Europasian Journal of Medical Sciences (EJMS) (www.europasianjournals.org) is an official Journal of Nirvana Psychosocial Care Center \& Ressearch Institute (www.nirvanapscc.com). The Journal as well as publisher remain neutral with regards to any jurisdictional claims in any published articles, its contents and the institutional affiliations of the authors. 


\section{INTRODUCTION}

Maternal health is one of the most important health indicators, and it indicates the overall health status of a country. ${ }^{1}$ Although maternal mortality has decreased by 38\% between 2000 to 2017, maternal mortality is still unacceptably high. In low and middle-income countries, $94 \%$ of all maternal deaths occur. ${ }^{2}$ According to Nepal Demographic and Health Survey (NDHS), the maternal mortality ratio (MMR) from 1996 to2016 has decreased from 539 to 239 maternal deaths per 100,000 live births. ${ }^{3}$ According to a systematic review conducted by World Health Organization, hemorrhage, sepsis, eclampsia, and pre-eclampsiaare the major causes of maternal death globally. ${ }^{4}$ Improving the health status of a region is not possible without improving the maternal health which is influenced by various socio-economic and demographic and several other factors. ${ }^{5}$ Antenatal care (ANC) is a broadly used approach to improve maternal and child health as well as to improve the rate of births attended by skilled health workers. ${ }^{6}$ The National Safe Motherhood Program of Nepal has recommended at least four ANC Checkup services scheduled as first visit at the $4^{\text {th }}$ month, second at the $6^{\text {th }}$ month, third at the $8^{\text {th }}$ month and fourth at the $9^{\text {th }}$ month of pregnancy.

In Nepal, the proportion of women who had four or more ANC visits has increased from $9 \%$ in 1996 to $69 \%$ in $2016 .{ }^{3}$ Those women who had better socio-economic and educational status and those living in urban area were more likely to visit skilled care personnel for ANC visits compared to those with low socio-economic status, less education and those living in rural areas. A further analysis of Nepal demographic and health survey revealed that those belonging to high caste had more ANC visits compared to the women from marginalized communities. ${ }^{8}$ Marginalized communities in Nepal are suffering from inequality in economic, social and political rights, opportunities and benefits. ${ }^{9}$ Thus the study was conducted to assess the prevalence and factors associated with ANCvisitsamong the marginalized community of Nepal.

\section{MATERIALS AND METHODS}

The dependent variable in the study was Antenatal care practice, which was dichotomized on into "less than 4 visits" and "4 or more visits" as recommended by government of Nepal during pregnancy?.

Age of the respondents was categorized into 3 groups: less than 20 years, 20-29 years, and more than or equal to 30 years. Educational status was categorized as illeterate, primary, some secondary, SLC and above. ${ }^{10}$ Occupation of mothers was categorized as agriculture, daily wages, and housewives. Occupation of husband was categorized as agriculture, business, daily wages and abroad workers. Age at marriage of mothers was categorized into less than 20 years and 20 or more years. ${ }^{11}$ The total number of members in the family was categorized into "less than 6" and "6 or more". Income has been categorized based on the salary scale of the Nepal Government, according to which NPR 19500 is used as a reference point to categorize the income of workers. ${ }^{12}$ The ethnicity of marginalized women included Dalit and Janajati. Parity of the mothers included nulliparous, primiparous, and multiparous. Decision-making person for ANC checkup was categorized as ownself, both husband and wife, and others. Perceived discriminatory behavior of health workers was categorized as "Yes' and "No". If the mothers said that they receivedall the services like iron supplementation, medical checkup, TT2+ injection, blood pressure checkup, intestinal drugs, and health education,then we classified the ANC services as "good", and in case any one of the components above were missing, we classified it as "poor." ${ }^{\text {"13 }}$

A community-based cross-sectional study was carried out in Sindhupalchowk district of Nepal from April - June, 2019 with mixed methods. According to Nepal Population and Housing Census 2011, the total population of the Municipality was 45343 , with 23614 males and 21729 females $^{14}$. Twowards of the municipality consisting of the highest number of marginalized people were selected for the study.A ward is the smallest administrative unit of a municipality.

Local resident mothers having childbirth during the last 2 years of the municipality were selected for the study. A list of eligible mothers was prepared with the help of health facilities and Female Community Health Volunteers of the municipality. This yielded a total of 202 eligible mothers who were enrolled in the study. For the qualitative part, we carried out interviews with a health-post in-charge, a ward chairperson, $\mathrm{FCHV}$, an auxiliary nurse midwife, and a school teacher.

A pre-tested structured questionnaire was used for the collection of quantitative data, and key informant interview guidelines were used for the collection of qualitative data. The questionnaire and key informant interview guidelines were translated 
into the local language and were administered to the respondents by the investigators themselves. Ethical approval was taken from the Ethical Review Board (ERB) of Nepal Health Research Council. Written informed consent was taken from the

Table 1: socio-demographic and socioeconomic characteristics of the respondents

\begin{tabular}{|c|c|}
\hline Characteristics & Frequency (\%) \\
\hline \multicolumn{2}{|c|}{ Mother's age in years (mean: 26.7, SD: 6.3) } \\
\hline$<20$ & 20(9.9) \\
\hline $20-29$ & $126(62.4)$ \\
\hline$\geq 30$ & $56(27.7)$ \\
\hline \multicolumn{2}{|l|}{ Mother's Education } \\
\hline Illiterate & $46(22.8)$ \\
\hline Primary & $127(62.9)$ \\
\hline Some secondary & $29(14.4)$ \\
\hline \multicolumn{2}{|l|}{ Husband's education } \\
\hline Illiterate & $20(9.9)$ \\
\hline Primary & $101(50.0)$ \\
\hline Some secondary & $47(23.3)$ \\
\hline SLC or higher & $34(16.8)$ \\
\hline \multicolumn{2}{|l|}{ Mother's occupation } \\
\hline Housewives & $59(29.2)$ \\
\hline Agriculture & $83(41.1)$ \\
\hline Daily wages & $60(29.7)$ \\
\hline \multicolumn{2}{|l|}{ Husband's occupation } \\
\hline Agriculture & $39(19.3)$ \\
\hline Business & $34(16.8)$ \\
\hline Abroad & $65(32.2)$ \\
\hline Daily wages & 64(31.7) \\
\hline \multicolumn{2}{|l|}{ Family number } \\
\hline$<6$ & $98(48.5)$ \\
\hline$\geq 6$ & $104(51.5)$ \\
\hline \multicolumn{2}{|l|}{ Age at marriage (years) } \\
\hline$<20$ & $126(62.4)$ \\
\hline$\geq 20$ & $76(37.6)$ \\
\hline \multicolumn{2}{|l|}{ Income (NPR) } \\
\hline$<19500$ & 127(62.9) \\
\hline$\geq 19500$ & $75(37.1)$ \\
\hline \multicolumn{2}{|l|}{ Time to reach health facility } \\
\hline$<30$ minutes & $83(41.1)$ \\
\hline$\geq 30$ minutes & 119(58.9) \\
\hline \multicolumn{2}{|c|}{ Decision makingautonomy for health } \\
\hline Respondent alone & $72(35.6)$ \\
\hline Respondent and husband & $48(23.8)$ \\
\hline Husband alone and others & $82(40.6)$ \\
\hline
\end{tabular}

\begin{tabular}{|c|c|}
\hline Characteristics & Fdrequency (\%) \\
\hline \multicolumn{2}{|l|}{ Number of ANC visits } \\
\hline$<4$ visits & $87(43.1)$ \\
\hline$\geq 4$ visits & $115(56.9)$ \\
\hline \multicolumn{2}{|l|}{ Place of ANC visit } \\
\hline Government hospitals & $173(85.6)$ \\
\hline Private hospitals & $29(14.4)$ \\
\hline \multicolumn{2}{|l|}{ Parity of mothers } \\
\hline Nulliparous & $23(11.4)$ \\
\hline Primiparous & $90(44.6)$ \\
\hline Multiparous & $89(44.1)$ \\
\hline \multicolumn{2}{|l|}{ Exposure to FCHVs } \\
\hline Yes & $146(72.3)$ \\
\hline \multicolumn{2}{|c|}{ Know about the Safe Delivery Incentive Program } \\
\hline Yes & $154(76.2)$ \\
\hline \multicolumn{2}{|c|}{ Perceived discriminatory behavior of health worker } \\
\hline Yes & $42(20.8)$ \\
\hline \multicolumn{2}{|l|}{ Iron supplementation } \\
\hline Yes & $171(84.7)$ \\
\hline \multicolumn{2}{|l|}{ Medical Checkup } \\
\hline Yes & $172(85.1)$ \\
\hline \multicolumn{2}{|c|}{ Received TT2+ injection } \\
\hline $\begin{array}{l}\text { Yes } \\
\text { Blood pressure } \\
\text { measurement }\end{array}$ & 157(77.7) \\
\hline Yes & $163(60.7)$ \\
\hline \multicolumn{2}{|c|}{ Intestinal parasitic drug } \\
\hline Yes & 183(90.6) \\
\hline \multicolumn{2}{|l|}{ Health education } \\
\hline Yes & $174(86.1)$ \\
\hline \multicolumn{2}{|l|}{ Perceived quality ANC } \\
\hline Good & $102(50.5)$ \\
\hline Poor & $100(49.5)$ \\
\hline
\end{tabular}

respondents, and confidentiality of the information was ensured by maintaining privacy while collecting the data.

The collected data was edited manually to check for completeness and accuracy.Quantitative data was entered in Microsoft Excel 2013 and was analyzed using IBM SPSS Statistics version 23. Descriptive analysis was performed using frequency, percentage, mean and standard deviation. Bivariate and multivariate logistic regression analyses were carried out to find out the association between different predictors and the outcome. $p$ - value of less than 0.05 were considered statistically significant.Qualitative data were transcribed, translated form Nepali to English and thematic analysis was done.

\section{RESULTS}

The socio-demographic and socio-economic characteristics of the participants. The mean age 


\begin{tabular}{|c|c|c|c|c|c|c|}
\hline \multirow[b]{2}{*}{ Characteristics } & \multicolumn{2}{|c|}{ Antenatal Care Visit } & \multirow[b]{2}{*}{ COR (95\% C.I.) } & \multirow[b]{2}{*}{ P-value } & \multirow[t]{2}{*}{ AOR (95\% C.I.) } & \multirow[t]{2}{*}{ P-value } \\
\hline & $\begin{array}{l}<4 \text { ANC } \\
(n=87)\end{array}$ & $\begin{array}{l}\geq 4 \text { ANC } \\
(n=115)\end{array}$ & & & & \\
\hline \multicolumn{7}{|l|}{ Mother's age in years } \\
\hline$<20$ & $11(12.6)$ & $9(7.8)$ & 1 & & & \\
\hline $20-30$ & $54(62.1)$ & $72(62.6)$ & $1.6(0.63-4.20)$ & 0.313 & & \\
\hline$\geq 30$ & $22(25.3)$ & $34(29.6)$ & $1.9(0.67-5.30)$ & 0.227 & & \\
\hline \multicolumn{7}{|l|}{ Mother's Education } \\
\hline Illiterate & $30(34.5)$ & $16(13.9)$ & 1 & & 1 & \\
\hline $\begin{array}{l}\text { Primary } \\
\text { Secondary }\end{array}$ & $\begin{array}{l}47(54.0) \\
10(11.5)\end{array}$ & $\begin{array}{l}80(69.6) \\
19(16.5)\end{array}$ & $\begin{array}{l}3.2(1.57-6.46) \\
3.5(1.34-9.46)\end{array}$ & $\begin{array}{l}0.001^{*} \\
0.011^{*}\end{array}$ & $\begin{array}{l}2.7(1.09-7.07) \\
2.1(0.57-7.8)\end{array}$ & $\begin{array}{l}0.034^{*} \\
0.259\end{array}$ \\
\hline \multicolumn{7}{|l|}{ Husband's education } \\
\hline Illiterate & $13(14.9)$ & $7(6.1)$ & 1 & & 1 & \\
\hline $\begin{array}{l}\text { Primary } \\
\text { Some Secondary }\end{array}$ & $\begin{array}{l}45(51.7) \\
21(24.1)\end{array}$ & $\begin{array}{l}56(48.7) \\
29(25.2)\end{array}$ & $\begin{array}{l}2.3(0.85-6.27) \\
2.9(1.005-8.90)\end{array}$ & $\begin{array}{l}0.10 \\
0.049 *\end{array}$ & $\begin{array}{l}1.25(0.33-4.78) \\
1.52(0.34-6.69)\end{array}$ & $\begin{array}{l}0.736 \\
0.578\end{array}$ \\
\hline \multicolumn{7}{|l|}{ Mother's occupation } \\
\hline Housewives & $21(24.1)$ & $38(33.0)$ & $2.3(1.13-4.95)$ & $0.022^{*}$ & $1.02(0.36-2.85)$ & 0.97 \\
\hline Agriculture & $32(36.8)$ & $51(44.3)$ & $2(1.06-4.09)$ & $0.033^{*}$ & $1.2(0.50-3.2)$ & 0.60 \\
\hline Daily wages & $34(39.1)$ & $26(22.6)$ & 1 & & 1 & \\
\hline \multicolumn{7}{|l|}{ Husband's occupation } \\
\hline Agriculture & $13(14.9)$ & $26(22.6)$ & $2.7(1.19-6.28)$ & $0.017^{*}$ & $2.2(0.72-6.88)$ & 0.16 \\
\hline $\begin{array}{l}\text { Business } \\
\text { Abroad }\end{array}$ & $\begin{array}{l}12(13.8) \\
25(28.7)\end{array}$ & $22(19.1)$ & $2.5(1.06-5.94)$ & $0.036 *$ & $1.5(0.47-4.78)$ & 0.49 \\
\hline Daily wages & $37(42.5)$ & $27(23.5)$ & 1 & & 1 & \\
\hline \multicolumn{7}{|l|}{ Family number } \\
\hline$<6$ & $39(44.8)$ & $59(51.3)$ & 1 & & & \\
\hline$\geq 6$ & $48(55.2)$ & $56(48.7)$ & $0.77(0.44-1.34)$ & 0.362 & & \\
\hline \multicolumn{7}{|l|}{ Age at marriage (years) } \\
\hline$<20$ & $62(71.3)$ & $64(55.7)$ & 1 & & 1 & \\
\hline$\geq 20$ & $25(28.7)$ & $51(44.3)$ & $1.9(1.09-3.57)$ & $0.023^{*}$ & $2.37(1.08-5.22)$ & $0.032^{*}$ \\
\hline \multicolumn{7}{|l|}{ Income (NPR) } \\
\hline$<19500$ & $62(71.3)$ & $65(56.5)$ & 1 & & 1 & \\
\hline$\geq 19500$ & $25(28.7)$ & $50(43.5)$ & $1.9(1.05-3.45)$ & $0.032^{*}$ & $1.4(0.60-3.21)$ & 0.43 \\
\hline \multicolumn{7}{|c|}{ Time to reach health facility } \\
\hline$<30$ minutes & $34(39.1)$ & $49(42.6)$ & 1 & & & \\
\hline$\geq 30$ minutes & $53(60.9)$ & $66(57.4)$ & $0.86(0.49-1.52)$ & 0.614 & & \\
\hline \multicolumn{7}{|c|}{ Decisionmakingautonomy for health } \\
\hline Respondent alone & $26(29.9)$ & $46(40.0)$ & $2.2(1.18-4.32)$ & $0.014^{*}$ & $2.9(1.22-6.96)$ & $0.015^{*}$ \\
\hline $\begin{array}{l}\text { Respondent and } \\
\text { husband }\end{array}$ & $15(17.2)$ & $33(28.7)$ & $2.8(1.32-5.95)$ & $0.007^{*}$ & $2.1(0.81-5.7)$ & 0.12 \\
\hline $\begin{array}{l}\text { Husband alone and } \\
\text { others } \\
\text { Place of ANC visit }\end{array}$ & $46(52.9)$ & $36(31.3)$ & 1 & & 1 & \\
\hline Government hospitals & $72(82.8)$ & $101(87.8)$ & 1 & & & \\
\hline Private hospitals & $15(17.2)$ & $14(12.2)$ & $0.66(0.302-1.464)$ & 0.309 & & \\
\hline \multicolumn{7}{|l|}{ Parity of mothers } \\
\hline Nulliparous & $8(9.2)$ & $15(13.0)$ & $2.1(0.80-5.44)$ & 0.128 & $1.6(0.48-5.81)$ & 0.416 \\
\hline Primiparous & $32(36.8)$ & $58(50.4)$ & $2(1.11-3.69)$ & $0.021^{*}$ & $1.6(0.76-3.57)$ & 0.204 \\
\hline Multiparous & $47(54.0)$ & $42(36.5)$ & 1 & & 1 & \\
\hline \multicolumn{7}{|l|}{ Exposure to FCHVs } \\
\hline No & $31(35.6)$ & $25(21.7)$ & 1 & & 1 & \\
\hline Yes & $56(64.4)$ & $90(78.3)$ & $2(1.068-3.71)$ & $0.030^{*}$ & $2.5(1.1-5.9)$ & $0.030^{*}$ \\
\hline Know about Safe Deli & y Incentiv & rogram & & & & \\
\hline No & $30(34.5)$ & $18(15.7)$ & 1 & & & \\
\hline & $57(65.5)$ & $97(84.3)$ & $2.8(1.45-5.54)$ & $0.002^{*}$ & $3.6(1.46-9.0)$ & $0.006^{*}$ \\
\hline Perceived discriminat & behavior & health wor & & & & \\
\hline No & $69(79.3)$ & $91(79.1)$ & $1.01(0.50-2.0)$ & 0.975 & & \\
\hline Yes & $18(20.7)$ & $24(20.9)$ & 1 & & & \\
\hline Perceived good quali & NC & & & & & \\
\hline No & $62(71.3)$ & $38(33.0)$ & 1 & & 1 & \\
\hline Yes & $25(71.3)$ & 77 (67.0) & $5(2.74-9.20)$ & $<0.001^{*}$ & $7.5(3.3-17.1)$ & $<0.001^{*}$ \\
\hline
\end{tabular}


of the participants was 26.7 years. More than two-third $(70.3 \%)$ of the participants followed Buddhistreligion, and more than two-third (70.8\%) were of Janajati ethnic group. Among the participants, three in five $(62.9 \%)$ had primary level of education. Half (50.0\%) of the participants' husbands had primary level of education. Regarding the occupation of the participants, more than two-fifth (41.1\%) were engaged in agriculture. Almost one-third (32.3\%) of the participants' husbandsworked abroad. More than three in five (62.4\%) were married before the age of 20 years, and almost two-third (63\%) had a family income of less than NPR 19500.For three in five (58.9\%) of the participants, the distance to reach the health facility was more than 30 minutes, and more than one -third (35.6\%) of the participants made the decision by themselves for their own health (Table 1).

The health-related characteristics of the participants. Key informants such as health facility in-charge and auxiliary midwife also stated that the women from the marginalized communities had incomplete ANC visits (table 2).

In the bivariate analysis (table 3), the sociodemographic and socio-economic characteristics like mothers' education, husbands' education, mothers' occupation, husbands' occupation, age at marriage, and family income were significantly associated with of the number of ANC visits. Similarly, the characteristics like "decision-making autonomy for health by the participants", parity, "exposure to FCHVs", and "perceived quality of $A N C$ " were significantly associated with the number of ANC visit.

Table 3 also shows the multivariate analysis of the characteristics of the participants and the ANC visits. Mothers education was significantly associated with ANC visits in which those with primary education were 2.7 times more likely to complete four or more ANC visits (AOR: 2.7, Cl: 1.09-7.07). Key informants also echoed the fact that those women who were from the marginalized community were less likely to complete 4 ANC visits. The participants who had married at 20 years of age or late were 2.3 times more likely to complete four or more ANC visits (AOR: 2.3, Cl: 1.08-5.22).

The women who took decisions alone for their health were almost three times more likely to complete four or more ANC visits (AOR: 2.9, Cl: 1.22-6.96). According to the FCHVs and other health personnels, most of the mothers in the families of the marginalized community were not allowed to take the decision on their own affecting their health-seeking behavior, including the ANC visits.Most of the decisions were taken by their husbands or their mother-in-laws or both.

Exposure to FCHV (AOR:2.5, Cl: 1.1-5.9) and knowledge about safe delivery incentive program (AOR: 3.6, Cl: 1.46-9.0) were statistically significant with the number of ANC visits. According to the health personnel and FCHVs, they said that they visited the marginalized community frequently to make them aware of the importance of a minimum of four ANC visits and institutional delivery. According to the chair of a ward, "there may be some [communication] gaps between the marginalized community and health personnel. [May be]The health personnel could not make them aware ofthe importance of safe motherhood, which should be addressed by all of us."

Perception of "good quality" ANC service was highly significantly associated with the number of ANC visits (AOR:7.5, Cl: 3.3-17.1). According to the health personnel, the women visiting the health facilities for ANC got all the services like iron supplementation, intestinal drugs, measurement of blood pressure, medical checkup, TT2+ injection, and health education. The healthpostincharge in his own words, "Some women might have a preoccupation in their mind that they don't get adequate services when they visit here, we are continuing to increasing awareness through home visits and outreach clinics."

\section{DISCUSSION}

The mixed-method study was conducted among marginalized community of Sindhupalchowk district, Nepal. The study found that more than half (56.9\%) of the participants had given birth during the last 2 years had four or more ANC visits which is almost equal to a study conducted in Gorkha among the marginalized community and in a rural area of Banke district of Nepal. ${ }^{15,16}$ Similar study conducted in Mahottari district of Nepal found that the women had lower four or more ANC visits than this study. ${ }^{13}$

Age of the participants in not significantly associated with the utilization of $A N C$, and the finding is supported by a study conducted in Mahottari of Nepal. ${ }^{13}$ The finding is not supported by a study conducted in Gorkha district of Nepal. ${ }^{16}$ In this study, the participants of higher age have higher odds than the participants with lower 
age. The participants with higher ages may have experienced previous pregnancies and may be aware of the shortcomings of poor ANC utilization.

Women with a higher level of education were more likely to complete atleast four ANC visits. The Nepal Demographic and Health Survey also has shown that mothers with higher education had a higher proportion of four or more ANC visits. ${ }^{17}$ Different studies conducted in Nepal and other parts of the world have shown education level of mothers to be associated with four or more ANC visits. ${ }^{13,15,16,18-}$ ${ }^{20}$ Higher the education of mothers, more the mothers will be aware of the health services and more the mothers will utilize the sexual and reproductive health services from the skilled health personnel.Husband'seducation has not shown to be significantly associated with ANC practice and is supported by a study conducted in Nepal and Rwanda. ${ }^{18,21}$ A study conducted in Terai region of Nepal does not support the finding. ${ }^{13}$ Occupation of the participants has not shown be significantly associated with ANC practice and is supported by some studies. ${ }^{18,22-24}$ participants' occupation was significantly associated with ANC practice in a study conducted among marginalized community in Nepal. ${ }^{13}$ The different findings may be due to the different ecological regions of the study. Occupation of participants' husband also did not show significant association with ANC practice and is in agreement with studies conducted in Nepal and different parts of the world. ${ }^{13,15,18}$ Family size was not significantly associated and is in agreement with a similar study of Nepal. ${ }^{13}$ The mothers who were married at 20 years or more than 20 years were more likely to complete 4 or more ANC visits and the association was statistically significant. These findings were echoed in the studies conducted in India. ${ }^{25,26}$

In this study, income was not significantly associated with ANC visits and is in agreement with a similar study conducted in Mahottari district of Nepal ${ }^{13}$ but different studies conducted in different parts of Nepal are in disagreement with the findings of this study. 20,21,27 Studies conducted in India are also in disagreement with the findings of this study. 22,24 This may be because ANC services are free in Nepal so, income may not necessarily be associated with ANC practices. Time to reach health facility is not associated with ANC visit and the finding is similar to a study conducted in Nepal and India. ${ }^{13,28}$ The time to reach the health facilities in the wards of municipalities was not more than one hour due to which it may not be associated with ANC visit.
Decision making autonomy is very crucial for mothers in the families.Ina country like Nepal, women have to rely on their husband and family members (mostly in-laws) to take any decision. Different studies have shown that decision making automy plays a significant role in the utilization of maternal health services. ${ }^{13,16,20,28,29}$ In this study, decision making autonomy for health was significantly associated with ANC visits. Place of ANC visit did not play significant role in this study. Studies have shown that multiparous women, due to their previous experiences may not feel the need of ANC. ${ }^{29-31}$ Parity of women was not significantly associated with ANC visits and is in agreement with studies conducted in Mahottari district and eastern Nepal. ${ }^{13,32}$ Exposure of mothers to FCHVs is significantly associated with ANC visits and is supported by a study conducted in Nepal support the finding. ${ }^{13}$ In a country like Nepal, FCHVs have played a significant role in increasing the utilization of maternal health services. In this study, the participants exposed to FCHVsmay have received the information regarding the ANC services. The participants who knew about safe delivery incentive program were more than 3 times more likely to complete 4 or more ANC visits. The finding is supported by some studies conducted in Nepal. ${ }^{13,33}$ There was no discriminatory behaviour of the health workers in the study which is supported by a study conducted in India. ${ }^{34}$ The perceived "good quality" ANC was highly significantly associated with ANC visits and is supported by studies of Nepal and Northern Ethiopia. ${ }^{13,35,36}$

Different factors like educational status of mothers, age at marriage, decision-making role in the family for seeking health services, exposure to FCHVs, know about safe delivery incentive program and perceived "good quality" ANC had played significant role in the utilization of ANC among the women of marginalized community.

\section{CONCLUSION}

Regardless of free safe motherhood services in government hospital, utilization of ANC was considerably low among the women in the marginalized community of Melamchi Municipality. The study also revealed that educational status of mothers, age at marriage, decision-making role in the family for seeking health services, exposure to FCHVs, knowledge about safe delivery incentive program and perceived "good quality" ANC played a significant role in ANC visits among the women of the marginalized community of Melamchi 
municipality of Sindhupalchowk district of Nepal. Community engagement and social awareness could play a very vital role to help increase uptake of safe motherhood services, thereby impacting the overall maternal health of these marginalized women in the future.

Acknowledgement: Authors would like to acknowledge all the participants who voluntarily participated in the study and all thehealth-post in-charge, a ward chairperson, FCHV, an auxiliary nurse midwife, and a school teacher who actively participated in providing qualitative information.

\section{REFERENCES}

1. Sajedinejad S, Majdzadeh R, Vedadhir AA, Tabatabaei MG, Mohammad K. Maternal mortality: A cross-sectional study in global health. Global Health. 2015;11(1):1-13. [Full Text] [PubMed]

2. Maternal mortality. World Health Organization. Accessed April 2, 2020. [Full Text] [Google Scholar]

3. Ministry of Health and Population. Nepal Demographic and Health Survey.; 2016. Accessed April 5, 2019. [Full Text] [Google Scholar]

4. Say L, Chou D, Gemmill A, et al. Global causes of maternal death: A WHO systematic analysis. Lancet Glob Heal. 2014;2(6). https://doi.org/10.1016/ S2214-109X(14)70227-X [Lancet]

5. Ju Hwang W, Mi Park Y. Factors influencing the accessibility of maternal health service in Cambodia. Int J Environ Res Public Health. 2019;16(16). https://doi.org/10.3390/ ijerph16162909 [Google Scholar]

6. von Both C, Fleßa S, Makuwani A, Mpembeni R, Jahn A. How much time do health services spend on antenatal care? Implications for the introduction of the focused antenatal care model in Tanzania. BMC Pregnancy Childbirth. 2006;6(1):22. https://doi. org/10.1186/1471-2393-6-22 [PubMed]

7. Safe Motherhood Programme. https://www.mohp. gov.np/eng/program/reproductive-maternalhealth/safe-motherhood-programme. Accessed March 30, 2020. [Google Scholar]

8. Kumar Aryal K, Sharma SK, Nath Khanal M, et al. DHS Further Analysis Reports No. 118 Maternal Health Care in Nepal: Trends and Determinants Ministry of Health and Population.; 2019. Accessed April 3, 2020. [Full Text] [Google Scholar]

9. The State Ignores Minority And Marginalized. [Full Text]. Accessed April 3, 2020. [Google Scholar]

10. Kathmandu E. Nepal Demographic and Health Survey 2011 Population Division Ministry of Health and Population Government of Nepal Kathmandu, Nepal.; 2012. [Full Text] Accessed January 7, 2020.

\section{[Google Scholar]}

11. The National Civil (Code) Act, 2017 (2074).; 2017. http://www.moljpa.gov.np/en/wp-content/ uploads/2018/12/Civil-code.pdf. Accessed April 4, 2020. [Google Scholar]

12. New Salary Scale of All Government Employee of Nepal Published: valid from 2076 Shrawan - Exam Sanjal. Accessed March 31, 2020. [Full Text] [Google Scholar]

13. Chaurasiya SP, Pravana NK, Khanal V, Giri D. Factors Affecting Antenatal Care Utilization Among the Disadvantaged Dalit Population of Nepal: A Cross- sectional Study. Open Public Health J. 2019;12(1):155-163. https://doi. org/10.2174/1874944501912010155 [PubMed]

14. Kathmandu N. National Population and Housing Census 2011 Social Characteristics Tables Government of Nepal National Planning Commission Secretariat Central Bureau of Statistics.; 2014. Accessed April 7, 2020. [Full Text] [Google Scholar]

15. Paudel RK, Thepthien B, Hong SA. Factors Related to Regular Use of ANC Services among Mothers of Children under One Year of Age in Rural Communities of Banke District, Nepal. Asian Pacific J Heal Sci. 2016;3(3):216-222. https://doi. org/10.21276/apjhs.2016.3.3.34 [Google Scholar]

16. Awasthi MS, Awasthi KR, Thapa HS, Saud B, Pradhan S, Khatry RA. Utilization of antenatal care services in dalit communities in gorkha, Nepal: A cross-sectional study. J Pregnancy. 2018;2018. https://doi.org/10.1155/2018/3467308 [PubMed]

17. Ministry of Health and Population (MOHP). Nepal Demographic and Health Survey.; 2011. https:// doi.org/10.1007/978-94-6091-391-4_15 [Google Scholar]

18. Rurangirwa AA, Mogren I, Nyirazinyoye $L$, Ntaganira J, Krantz G. Determinants of poor utilization of antenatal care services among recently delivered women in Rwanda; a population based study. BMC Pregnancy Childbirth. 2017;17(1):110. https://doi.org/10.1186/s12884-017-1328-2 [PubMed]

19. Shrestha B. Mother's Education and Antenatal Care Visits in Nepal. Tribhuvan Univ J. 2018;32(2):153164. doi:10.3126/tuj.v32i2.24712 [Google Scholar]

20. Joshi C, Torvaldsen S, Hodgson R, Hayen A. Factors associated with the use and quality of antenatal care in Nepal: a population-based study using the demographic and health survey data. BMC Pregnancy Childbirth. 2014;14(1):94. https://doi. org/10.1186/1471-2393-14-94 [PubMed]

21. Sharma D, Pokharel HP, Budhathoki SS, Yadav BK, Pokharel RK. Antenatal Health Care Service Utilization in Slum Areas of Pokhara Sub- 
Metropolitan City, Nepal. J Nepal Health Res Counc. 2016;14(32):39-46. [Google Scholar]

22. Shekhawat R, Sharma N, Kashyap A, Sodha VS. Utilization of Antenatal Care Services and Its Determinants in Rural Field Practice Area of Jaipur, India. Natl J Community Med. 2018;9(12):875-878. [Google Scholar]

23. Olayinka A, Joel A, Bukola D. Factors influencing utilization of antenatal care services among pregnant women in Ife Central Lga, Osun State Nigeria National Hospital Abuja, Nigeria. Adv Appl Sci Res. 2012;3(3):1309-1315. [Google Scholar]

24. Kakati R, Barua K, Borah M. Factors associated with the utilization of antenatal care services in rural areas of Assam, India. Int J Community Med Public Heal. 2016;3(10):2799-2805. https://doi. org/10.18203/2394-6040.ijcmph20163364 [Google Scholar]

25. Paul P, Chouhan P. Association between child marriage and utilization of maternal health care services in India: Evidence from a nationally representative cross-sectional survey. Midwifery. 2019;75:66-71. https://doi.org/10.1016/j. midw.2019.04.007

26. Chauhan A. Antenatal care among currently married women in Rajasthan, India. Asian Pacific J Trop Dis. 2012;2(SUPPL2). http://doi.org/10.1016/ S2222-1808(12)60232-1 [Science Direct]

27. Pandey S. Socio-economic and Demographic Determinants of Antenatal Care Services Utilization in Central Nepal. Int J MCH AIDS. 2013;2(2):212219. https://doi.org/10.21106/ijma.27 [PMC]

28. Ogbo FA, Dhami MV, Ude EM, et al. Enablers and barriers to the utilization of antenatal care services in India. Int J Environ Res Public Health. 2019;16(17):1-14. https://doi.org/10.3390/ ijerph16173152 [Google Scholar]

29. Ali SA, Dero AA, Ali SA, Ali GB. Factors Affecting the Utilization of Antenatal Care among Pregnant Women in Moba Lga of Ekiti State, Nigeria. Int J
Tradit Complement Med. 2016;2(2):41-45. https:// doi.org/10.28933/sina-ijtcm-2016 [Google Scholar]

30. Zhao Q, Huang ZJ, Yang S, Pan J, Smith B, Xu B. The utilization of antenatal care among rural-tourban migrant women in Shanghai: A hospitalbased cross-sectional study. BMC Public Health. 2012;12(1):1. https://doi.org/10.1186/1471-245812-1012 [PubMed]

31. Tran TK, Gottvall K, Nguyen HD, Ascher H, Petzold $M$. Factors associated with antenatal care adequacy in rural and urban contexts-results from two health and demographic surveillance sites in Vietnam. BMC Health Serv Res. 2012;12(1):40. https://doi. org/10.1186/1472-6963-12-40 [PubMed]

32. Ramesh Kumar Dahal. Utilization of Antenatal Care Services in Rural Area of Nepal. Int J Collab Res Intern Med Public Heal. 2013;5(2):120-131. [Google Scholar] [Full Text]

33. Deo KK, Paudel YR, Khatri RB, et al. Barriers to Utilization of Antenatal Care Services in Eastern Nepal. Front Public Heal. 2015;3(August):1-7. https://doi.org/10.3389/fpubh.2015.00197 [PubMed]

34. Dahal M, Baral K, Angolkar M. Utilization of Maternal Health Care Services in India: A Community Based Cross-sectional Study in Rural Belgaum. J Adv Med Med Res. 2019;(March):1-11. https://doi.org/10.9734/jammr/2019/v29i330069 [Google Scholar]

35. Fesseha G. Perceived Quality of Antenatal Care Service by Pregnant Women in Public and Private Health Facilities in Northern Ethiopia. Am J Heal Res. 2014;2(4):146. https://doi.org/10.11648/j. ajhr.20140204.17 [Google Scholar]

36. Parajuli SB, Shrestha S, Sah A, Heera KC, Amgain K, Pyakurel P. Role of Female Community Health Volunteers for Prevention and Control of COVID-19 in Nepal. Journal of Karnali Academy of Health Sciences. 2020; 7(1):1-8. 